\title{
A MEDUSA E O GOZO: UMA LEITURA DA DIFERENÇA SEXUAL EM PSICANÁLISE
}

Maria Cristina Poli

Psicanalista, membro

da Associação

Psicanalítica de Porto

Alegre. Doutora

em Psicologia

pela Universidade

de Paris 13 e

pós-doutora pelo

Programa de Pós-

graduação em Teoria

Psicanalítica da

UFRJ. Professora

do Programa de

Pós-graduação em

Psicologia Social da UFRGS
RESUMO: Pretende-se retomar, nas obras de Freud e Lacan, algumas das principais balizas do estatuto da diferença sexual em psicanálise. O enigma feminino, assinalado por Freud, e as diferentes formas de gozo, referidas por Lacan, situam o registro da referida diferença. Por fim, algumas contribuições de Foucault nos permitem avaliar a implicação política da psicanálise em relação a esse tema.

Palavras-chave: Diferença sexual, psicanálise, castração, identidade sexual.

ABSTRACT: The Medusa and the joy: a reading of the sexual difference in psychoanalysis. This article revisits the texts of Freud and Lacan, indicating some of the main beacons of the statute of the sexual difference in psychoanalysis. The feminine enigma, designated from Freud, and the different forms of joy, related from Lacan, point out the register of the sexual difference in psychoanalysis. Some contributions of Foucault allow for the politic implication of the psychoanalysis in relation to this subject.

Keywords: Sexual difference, psychoanalysis, castration, sexual identity.

\section{INTRODUÇÃO}

Nos últimos anos, os autores conhecidos como pertencentes aos estudos de gênero (gender studies) têm aportado importantes contribuições no campo da sexualidade (BUTLER, 2003). Território inicialmente colonizado e dominado pela psicanálise, encontrou em Foucault um antecedente dessa leitura crítica ao inscrever Freud no contexto discursivo de sua produção. A repressão não suprime a sexualidade, insiste o filósofo; ela faz parte de um dispositivo mais amplo que a incita (FOUCAULT, 1988).

Hoje, boa parte da psicanálise incorporou tais elementos, incluindo os dispositivos discursivos na consideração da 
relação do sujeito ao sexo. A releitura de Freud, empreendida por Lacan, buscou resgatar o sentido de sua obra. Isso significa destacar os efeitos subversivos de seu texto, sem deixar-se tomar demasiado pelas armadilhas dos modelos nos quais ele se apoiou para suas elaborações conceituais (ALTHUSSER, 1985).

Entre a psicanálise e os estudiosos do gênero, porém, algo permanece dificultando, de parte a parte, uma elaboração comum, ou ao menos um diálogo mais profícuo que permita avançar em questões de extrema atualidade e relevância. A tematização da "diferença sexual” nas obras de Freud e de Lacan parece ser um desses pontos sobre o qual impera um “desconhecimento seletivo”. Ela é sempre re-evocada para reafirmar preconceitos históricos, certamente que não de todo desprovidos de fundamento, mas também já enferrujados pelo jargão.

Retomemos, portanto, dentro dos limites que esse artigo nos permite, alguns elementos fundamentais da contribuição de Freud e Lacan para a teorização da diferença entre os sexos. Esperamos com isso poder avançar, em trabalhos futuros, no debate com os autores dos “estudos de gênero" partindo de um melhor discernimento sobre os fundamentos dessa questão na psicanálise.

\section{A DIFERENÇA ENTRE OS SEXOS, SEGUNDO FREUD}

Segundo Freud (1931/1973), até certo ponto do desenvolvimento psicossexual, meninos e meninas caminham na mesma direção, compartilham a mesma constituição. Há um momento, no entanto, a partir do qual elas podem se tornar também mulheres. Na sexualidade infantil, a disposição masculina é predominante: tanto a libido, pela sua tendência à atividade, quanto o desconhecimento da diferença entre os sexos pelo inconsciente, dominado pela primazia do falo. Para que a feminilidade possa emergir é preciso um trabalho a mais.

Mas o que é, afinal, a feminilidade? É um dos destinos possíveis do complexo de Édipo nas mulheres, como demonstra Freud (1924/1973). O que, segundo ele, se faz acompanhar de certa mácula: nunca superar por completo a inveja do pênis; jamais ter um supereu adequadamente estabelecido de modo a poder ocupar lugar de produção na cultura; viver para sempre presa às condições pré-edípicas da sexualidade e, portanto, a uma forma narcisista de amar (FREUD, 1914/1973). Porém, mesmo na obra de Freud há outras versões da feminilidade.

Já nos Três ensaios para uma teoria sexual (FREUD, 1905/1973) — texto inaugural de uma teoria psicanalítica da sexualidade - encontramos uma concepção que prioriza a via do exercício pulsional e não apenas as identificações edípicas. Depois de descrever algumas das características mais típicas da sexualidade nos meninos e nas meninas, há uma nota de rodapé, acrescentada em 1915, na qual o autor menciona a dificuldade na utilização dos termos "masculino" e "feminino" (p.1.223). Eles têm, escreve o psicanalista, ao menos três sentidos diferentes. São sinônimos de atividade e passividade, respectivamente; são atributos biológicos, 
associados à presença de glândulas específicas a cada sexo, produtoras de óvulos ou espermatozóides; por fim, são conceitos sociológicos, derivados da observação dos comportamentos dos indivíduos. Os sentidos biológico e sociológico, continua o autor, são bastante questionáveis e relativos. Apenas a primeira destas definições interessa ao psicanalista. Sempre presentes, em diferentes medidas, atividade e passividade definem a bissexualidade constitucional dos humanos.

Feminilidade corresponderia, assim, à posição de passividade pulsional, ao lado da atividade de cunho masculino. Neste sentido, homens e mulheres disporiam de ambas as tendências. A libido em si é masculina, escreve Freud (1905/1973, p.1.223); a busca pela satisfação pulsional que a mobiliza só pode ter o caráter de atividade. Mesmo quando se goza da posição passiva - ao se fazer de objeto para um Outro - trata-se de uma passividade ativamente produzida (FREUD, 1915/1973). Nesse sentido, a feminilidade seria uma produção secundária da libido, resultado da reflexibilidade no percurso pulsional.

Esta proposta freudiana convive lado a lado com a outra, que prioriza as identificações edípicas. Nos textos Sobre a sexualidade feminina (FREUD, 1931/1973) e $A$ feminilidade (FREUD, 1933/1973), o autor parece buscar uma conciliação. A predominância da passividade pulsional na definição do caráter feminino será abordada, então, concomitantemente aos impasses na superação do Complexo de Édipo. Segundo Freud, observa-se nas mulheres uma especial aderência à relação com a mãe, uma dificuldade particular de transpô-la e substituí-la. O intransponível no Édipo feminino se traduziria em uma tendência de fixação da libido às primeiras posições — oral, anal e fálica —, onde passividade e atividade convivem. As mulheres teriam por isso maior inclinação à bissexualidade do que os homens; neste tempo pré-genital, a passividade se liga à objetalização da criança diante do desejo materno e a atividade à reversão deste movimento na busca do domínio.

Neste sentido, as mulheres apresentariam uma tendência a manifestarem certo infantilismo e maior imaturidade na sexualidade do que os homens. Que se traduz pela dominância de fantasias sadomasoquistas e de relações de objeto parciais. Já a feminilidade propriamente dita indica a possibilidade de superação do pré-edípico pelo abandono da atividade pulsional e a reconciliação com a posição passiva. Isso, no entanto, só é possível se a menina "aceita" desprender-se da mãe e, com ela, do erotismo clitoridiano. Não se trata apenas de um recalque da atividade, mas de sua superação e substituição.

A passividade inerente à sexualidade feminina se traduz também pela tendência do retorno da agressividade à própria pessoa. O masoquismo, escreve Freud (1933/1973, p.3.166), é “autenticamente feminino”. Tanto nas pulsões eróticas quanto nas agressivas é pelo predomínio da passividade sobre a disposição bissexual infantil que "surge a mulher", conforme a expressão do autor. 
A assunção deste pólo do exercício pulsional funciona como selo de passagem pela castração. Nos homens, ao contrário, será a atividade fálica — promovida pela identificação ao pai e deslocamento do objeto materno (não substituição, como nas mulheres) a marca da masculinidade. A atividade se expressa como traço masculino no exercício sexual, na assunção de uma posição de domínio, e nas atitudes agressivas de exteriorização da pulsão de morte.

Já a predominância masculina nas realizações culturais é atribuída por Freud a vicissitudes da passividade primária neste sexo. É também das posições prégenitais passivas da libido que provém a energia que compõe o supereu nos homens. A submissão infantil do menino ao pai — os desejos eróticos passivos que tem em relação ao genitor - se transforma na passagem pelo Édipo em internalização da lei e dos ideais culturais. Daí que, muitas vezes, a culpa obsessiva seja a expressão sintomática desta passividade recalcada. Também a particular sensibilidade cultural e artística de homossexuais masculinos — como Leonardo da Vinci, a quem Freud (1910b/1973) dedica um importante ensaio — , sobretudo se a tendência erótica for inibida de seus fins.

Como se pode notar, a transposição do complexo de Édipo implica, em termos pulsionais, em diferentes destinos para a passividade. Para as mulheres, a sua assunção; para os homens, sublimação, recalque e inibição. O motor desta operação, segundo Freud (1925/1973), é a angústia de castração. Diante da possibilidade de ser desprovido do falo, que seu pênis representa, o menino abandona (recalca, sublima e inibe) a posição passiva que o mantém preso ou bem à mãe ou bem ao pai, na face invertida do Édipo. A menina, por seu lado, já foi privada do falo. É por frustração que ela será levada a abandonar a mãe e com ela as pulsões ativas. A passividade será transferida à relação com o pai. Mais uma vez, frustrada por dele também não receber o dom almejado, recalca o Édipo para não perder o amor dos pais. A feminilidade surge, então, quando a menina reporta o pedido que faz ao pai a um outro homem, de quem espera receber o pênis-bebê. Isto é, quando ela retorna, de forma ativa, à posição passiva que a levou ao pai.

Não é de se estranhar que tendo assim expresso as polaridades dos sexos, Freud se pergunte: “mas, afinal, o que quer uma mulher?". "Ela quer ser desejada” é a única resposta possível nesta disposição libidinal pela conciliação que promove entre atividade e passividade. O exercício de uma posição de atividade pulsional, propriamente dita, só será possível por meio da maternidade. Por isso, é como um dom que um homem pode lhe fazer que a mulher espera adquirir o falo, representado pelo filho.

A masculinidade, por sua vez, não é priorizada nos estudos de psicanálise, de modo geral, como uma operação específica (JERUSALINSKY et al., 2005). Isto porque se a considera, desde Freud, como a "via normal” do desenvolvimento. 
Sabe-se, no entanto, que a assunção da paternidade, por exemplo, exige da parte dos homens um trabalho psíquico considerável. Ser investido como representante da lei e designado como portador do falo simbólico são árduas tarefas, cujo peso se faz sentir sobretudo na clínica da neurose obsessiva.

No que diz respeito diretamente à sexualidade masculina, o horror à passividade é uma de suas características. Na passagem pelo Édipo, a posição passiva pode se confundir com a castração, levando o menino a repudiá-la. Freud (1927/1973) explica assim alguns casos de homossexualidade masculina e fetichismo. Recusando-se a aceitar a realidade da castração, alguns meninos recuam e tamponam a falta do pênis com um objeto substitutivo - o fetiche. Ou, então, buscam em seu objeto sexual a confirmação da existência do pênis que atribuíam à mãe, promovendo a inversão sexual.

A masculinidade propriamente dita será resultado da inscrição subjetiva da castração. Desse modo, podemos considerar que, assim como a feminilidade, ela também supõe uma operação psíquica que não está de todo determinada por uma teleologia psicossexual. Que o menino reconheça subjetivamente a falta do pênis nas mulheres - e em particular na mãe - comporta assumir o risco de perder também o seu; identificar-se ao pai e tomar-se ao encargo das insígnias fálicas implica também em aceitar certa passividade, sem com isso confundir-se com a posição objetal.

A castração feminiliza homens e mulheres. Em Freud, o pênis e o pai são suportes naturais do valor fálico. Não há, para o autor, distância entre o símbolo e sua encarnação imaginária. É algo do qual hoje se pode criticá-lo. Devemos a Lacan essa distinção que comporta a quebra da correspondência entre significante e órgão. Ela é coerente com a forma como esse autor considera a relação entre as palavras e as coisas, inscrevendo o referente no próprio campo da linguagem (LACAN, 1957/1998).

Castração simbólica é o termo que designa esse descolamento entre significante e objeto. Mais do que uma operação subjetiva, ela incide antes sobre o campo do Outro (LACAN, 1957-58/1999). Na obra de Magritte Traição das imagens, encontramos esse princípio demonstrado (FOUCAULT, 1988b; POLI, 2004). Mesmo que tal operação de castração já operasse como função na cultura, foi preciso algum tempo — historicamente datado — para que fosse reconhecida. A crítica feminista à redução do falo ao pênis é uma de suas conseqüências.

O falo, enquanto significante, refere à inscrição do desejo no lugar da hiância entre Nome e Coisa. Falo e castração são, portanto, termos correlativos. Numa construção rápida diríamos que a castração é a inscrição da falta que é significada pelo falo. Verso e reverso — Real e Simbólico — da mesma operação que tem a feminilidade e a masculinidade como efeitos de sentido. 


\section{SIGNIFICAÇÃO E VÉU DO DESEJO}

“A multiplicação dos símbolos fálicos significa a castração”, escreve Freud (1922/1973, p.2.697) a respeito da imagem da cabeça decapitada de Medusa, na qual os cabelos assumem a forma de serpentes. Representação da castração materna - acrescenta o autor — - a imagem condensa o horror à castração e seu repúdio. Ela apresenta o genital feminino ao mesmo tempo que substitui a falta de pênis pelas serpentes.

Tal representação iconográfica tem um interessante correlativo na história da psicanálise. Em 1955, Lacan adquiriu o quadro A origem do mundo, de Gustave Courbet (ROUDINESCO, 1994). A obra, hoje em exposição no Museu d'Orsay, apresenta o corpo de uma mulher deitada, nua dos seios até as cochas, exposto ao expectador. A vulva sobressai em primeiro plano, numa representação que prima pelo realismo. Enquanto lhe pertencia, Lacan mantinha o quadro exposto na sua casa de campo, mas encoberto por uma outra tela, de André Masson, encomendada para este fim.

A visão dos genitais femininos, se não desperta necessariamente horror, provoca um desconcertante impacto. Suas representações na arte são veladas, destacando-se os índices de beleza feminina como substitutos fetichistas da castração. Mesmo na nudez do carnaval brasileiro, brilhos e purpurinas, silicones e depilações extremas, fazem do corpo todo da mulher ícone da sensualidade ao encobrir seu sexo. A mulher-objeto-de-desejo faz a máscara do falo, colocando no lugar da castração a apresentação de uma imagem corporal plena. Belle indifférence tipicamente feminina que denega de modo estratégico o desejo, fazendo do não a marca de sua presença.

Jogos de presença e ausência que designam ao falo sua dupla função de significante que nomeia o desejo ao indicar o lugar da falta. Na audaciosa tela de Courbet, retrata-se a moderna sabedoria do pintor para quem tinta e pincel já são suficientes para velar ao duplicar. Ao expectador a tarefa de, diante da mensagem que o quadro veicula, produzir significação, isto é, implicar-se como sujeito na produção de um sentido comum ao ver e ser visto. $A$ origem do mundo nomeia o autor a partir deste outro lugar. E o realismo de imediato adquire valor de metáfora a significar o desejo do qual somos todos tributários. Função significante da representação pictórica: significação do desejo, véu da falta.

Recentemente, a artista francesa Orlan, fundadora do movimento "arte carnal”, apresentou uma obra chistosa: A origem da guerra (ORLAN, 1989/2006). Na imagem, o mesmo recorte de cena, a mesma posição do corpo e do enquadre: o corpo de um homem com pênis em ereção. Obra feminista, evidentemente, que julgamos de início de valor duvidoso. Seu caráter de réplica reduz a metáfora de Courbet à expressão metonímica da diferença anatômica. Orlan reintroduz, na interpretação que faz da diferença entre os sexos, uma simetria da hierarquia 
que pretenderia criticar. Auto-armadilha que o movimento feminista em geral cai ao reproduzir em espelho o rebaixamento e a derrisão do qual as mulheres foram historicamente objeto. ${ }^{1}$

Por outro lado, a obra produz um efeito interessante. Se ela é, como dissemos, chistosa, é bem porque a imagem de um pênis em ereção é apresentada em uma posição tipicamente feminina: deitado, a espera de ser possuído. Imagem desconcertante que provoca o riso pelo contraste. Ao denominá-lo A origem da guerra, a artista indica o trabalho da metáfora que está em causa. É pela posse deste pênis/falo, deste grande desejo em ereção, que os humanos brigam. Não se trata, neste ponto, de nenhuma acusação de cunho feminista. Efetivamente, independente do gênero, o desejo é ele mesmo o objeto que move as paixões mais insanas e beligerantes. Sem necessidade de disfarces — posto que a imagem em si do pênis em ereção já é secundária, já é uma metáfora do desejo - ela coaduna suporte corporal e objeto causa de desejo. Literalmente: há um sujeito que deseja; este desejo espera ser possuído por alguém que o satisfaça. Pedido irrecusável para mulheres e homens. Por isso também, para eles como para elas, o gozo sexual é uma celebração ao falo. Oferecido à dama, cumpre a ambos fazê-lo gozar.

Harmonia entre os sexos em prol do gozo sexual? Cena encobridora; esquece-se facilmente que o pênis, mesmo em ereção, não é o falo, apenas seu representante imaginário. Assim como o não da mulher sedutora: metáfora do desejo. O falo é o significante que ao produzir a significação do desejo, produz o equívoco. Deste desejo, no entanto, se ele é a condição de sua significação (LACAN, 1958/1998) — efeito de limitação que a representação produz na abertura infinita da pulsão - , é bem porque mantém aberta a hiância que o move, possibilidade contínua de inclusão do sujeito na sua produção.

A inscrição subjetiva desse significante sexualiza o desejo na mesma medida que rompe definitivamente com a possibilidade de satisfação. A clivagem é, pois, seu principal efeito no sujeito. Freud (1910/1973; 1912/1973) identifica suas manifestações: o rebaixamento erótico e a idealização da amada que torna tão difícil ao neurótico obsessivo (seja homem ou mulher) a junção entre sexo e amor; perigo eminente na mascarada histérica (em homens e mulheres, igualmente), que de tanto disfarçar o desejo com a recusa, acaba por se convencer do próprio engano.

\footnotetext{
${ }^{1}$ No site da artista (www.orlan.net/fr/, acessado em março de 2007) pode-se ler a respeito do trabalho "A origem da guerra" que ele "pourrait bien passer pour un canular" e que realiza um "détournement parodique" do quadro de Courbet "A origem do mundo". Desta análise, assinada por Carole Boulbès, depreende-se também a inscrição feminista da obra de Orlan, confirmada pela própria artista em entrevista concedida a Corinne Sacca Abadi, na qual afirma: "sou feminista" (www.apa.org.ar, acessado em março de 2007).
} 


\section{O CONTINENTE NEGRO EXISTE?}

Que a mulher seja um enigma, Freud não é o primeiro, e nem o último, a dizê-lo (FREUD, 1933/1973). Faz parte da tradição ocidental, que já foi por isso mesmo denominada de falocêntrica (BUTLER, 2003). O que significa reconhecer nesta tradição uma forma de organização do universo representacional, centralizado em um único significante ordenador, a partir do qual se estabelecem pares opositivos. Bem e mal, branco e preto, positivo e negativo, masculino e feminino, etc. são formas derivadas de uma cultura estabelecida sobre o princípio monoteísta: um deus, um nome, um lugar pleno ou vazio — formas equivalentes nesse contexto — de onde derivam todas as significações, a partir de onde se determina o valor de todas as coisas.

Princípio da criação. A íntima relação entre o tema das origens e a diferença sexual não escapou a Freud. No processo da psicogênese, ela perpassa seu trabalho sobre a cena primária. A pergunta das crianças sobre "De onde vêm os bebês?" é a matriz das teorias sexuais infantis (FREUD, 1905/1973). Ou seria a percepção da castração, a mola da curiosidade infantil? Freud expressou esta dúvida, deixando-a em suspenso (FREUD, 1925/1973). Ele sustenta, de todo modo, que a descoberta do sexo feminino enquanto tal - além da polaridade entre fálico e castrado — se dá apenas na puberdade. Apenas então, a vagina será reconhecida como “albergue do pênis e herdeira do seio materno” (FREUD, 1923/1973, p.2.700).

Antes de chegar aí, o jovem terá um trabalho psíquico considerável a fazer. Isto porque a possibilidade de representação do sexo feminino, como indica Freud (1923/1973), tem como condição a inscrição psíquica do corpo materno como corpo sexuado. A fantasia do púbere sobre a promiscuidade da mãe faz parte deste percurso (FREUD, 1909/1973). Representação medusiana, pois atribui à genitora uma condição de atividade e de domínio do falo. O reconhecimento da castração materna e, em decorrência, a sua condição de sujeito de desejo, é promotor de uma clivagem. Em parte, a representação do sexo da mulher deriva deste reconhecimento. Por outro lado, o campo materno permanece externo à operação da significação fálica, mantendo-se no registro do recalque originário.

O enigma do feminino é derivado desta impossibilidade de representação do sexo materno. O corpo da mãe é sempre, em alguma medida, o corpo do incesto (COSTA, 1998). A intervenção da função paterna no Édipo — como propõe Lacan — interdita e simboliza ao mesmo tempo. Mas há um resto desta operação que permanece insubssumível. No seminário 20, Mais, ainda, Lacan (1972-73/1985) demonstra que se trata de um fato decorrente da própria estrutura da linguagem. O universo constituído pelo código — o simbólico — encontra seus limites em dois pontos que tocam o inominável: o princípio da criação e o objeto da pulsão. Eles constituem o que em psicanálise conhecemos como Real. 
Do lado do objeto da pulsão, Lacan (1962-63/2005) denomina objeto a à série de recortes/restos corporais — seio, fezes, urina, olhar, voz — que perfazem o corpo compartilhado mãe-bebê. Não sendo nem de um, nem de outro, estes objetos primários são prototípicos do objeto-alvo da pulsão. Inapreensíveis, posto que não há no simbólico um significante que os nomeie, constituem as bordas erógenas do corpo. Freud (1923/1973) propunha que a genitalidade produz a síntese destes objetos parciais, dirigindo a pulsão a um objeto total, alguém do outro sexo. Em parte, o significante fálico tem esta função, mas ela nunca se dá de modo completo.

No outro extremo do simbólico está, justamente, o princípio unificador. A prerrogativa de que haja ao menos um significante que signifique o conjunto de todos os significantes existentes é uma necessidade do sistema simbólico. O monoteísmo é uma versão deste princípio na cultura. Deus é um dos nomes que se dá a este significante pressuposto. A mulher, acrescentaríamos com Lacan (197273/1985), é também um de seus nomes. Ambos são construções da fantasia que visam suprir a exigência lógica de um princípio que nomeie sem que ele mesmo seja nomeado. Essa condição lhe situa na exterioridade do sistema simbólico que constitui. Ou seja, ele mesmo escaparia à castração pois faria consistir a plena correspondência entre nome e coisa.

Daí que Lacan afirme, de forma provocativa, "A mulher não existe" (LACAN, 1971/1994, p.66). Pois, justamente, se as mulheres são, como Freud indica, uma posição subjetiva decorrente da inscrição do significante fálico, não há como pressupor ao conjunto das mulheres uma unidade em si mesma. Neste ponto, tornar-se mulher é resultado da operação de castração e esta singulariza ao inscrever o sujeito no simbólico. As mulheres, sim, existem: uma a uma. O universal, como demonstramos, participa do Real; não passa pela chancela da castração simbólica, necessária à constituição do feminino.

Por outro lado, porém, há algo nas mulheres — o materno — que resiste à simbolização. Assim, elas têm a particularidade de serem "não todas" na castração. Em parte, isso identifica o corpo feminino com o objeto — o objeto a da pulsão. Nesta posição, a mulher é causa do desejo, imagem substitutiva ao inapreensível objeto da pulsão. Mas, além disso, o significante "mulher" denomina uma condição de alteridade ao registro fálico que faz crer na completude do encontro sexual entre homens e mulheres. Se Lacan afirma que "A mulher não existe" é também para demonstrar — em outro de seus axiomas provocativos — que "não há, de que é impossível colocar-se a relação sexual” (LACAN, 1972-73/1985, p.17). Isto é, que o pleno encontro entre os sexos é uma ficção que move o desejo, mas que é estruturalmente inviável. Nem que mais não seja porque pressupõe a existência ontológica de dois sexos quando, no que diz respeito ao sujeito do inconsciente - e é a clínica que nos ensina isso - se trata antes de condições de gozo distintas. 


\section{PRAZER, GOZO OU AMOR?}

A psicanálise precisou passar por sua própria revolução kepleriana. Freud, como ele mesmo reconhece, acompanhou Copérnico ao demonstrar que não era a terra, mas o sol a referência da rotação celeste (FREUD, 1917/1973). Deslocamentos equivalentes: da racionalidade egóica ao desejo inconsciente. Coube a Lacan um passo a mais. Como Kepler que desvelou a elipse onde se supunha o círculo (LACAN, 1972-73/1985, p.59). Sem centro, o movimento é regulado pelo ponto de fuga; pela queda. Topologia barroca — desprovida de referentes especulares —, os significantes seguem rota própria, orientados não pelas ficções de sentido, mas pelo inapreensível objeto causa de desejo. Ponto de fuga em um referente infinito; ponto de queda na construção do sentido (POLI, 2005).

A produção de sentidos é estruturante da neurose, assim como o é a referência ao falo. Quando o neurótico pergunta-se "Serei eu homem?" ou "Serei eu mulher?" - mesmo que sua pergunta não seja pautada pela correspondência à anatomia - ele se engana. Isso porque ao enunciar tal dúvida, denuncia a crença na identidade sexual, que jamais dirá respeito à posição de enunciação do sujeito inconsciente (POLI, 2004). A construção de uma identidade homem ou mulher são produções sintomáticas da neurose. O sintoma visa suplantar o furo estrutural; ele tenta produzir uma analogia impossível entre real e simbólico.

Lacan (1972-73/1985) denomina essa busca pelo sentido de gozo fálico. Sua expressão subjetiva é o amor. Como Freud já indicara, o amor (Eros) visa à unidade, ele se pauta pela miragem do fazer Um. É nesse sentido também que ele corresponde ao narcisismo: a constituição de uma unidade egóica comporta esta ilusão de completude com o Outro. Que os dois sexos possam ser complementares no amor diz respeito à ilusão narcisista de reciprocidade. Do ponto de vista da psicanálise, diríamos antes — com Lacan — , que o amor é suplementar à falta do gozo sexual. Mesmo que seja uma crença enganosa, poder amar é uma decorrência da castração. É, de alguma forma, um deixar-se enganar. Como escreve, poeticamente, Lacan (196465/2000, p.224): “amar é dar o que não se tem a quem não o quer”.

Acreditar que homens e mulheres constituam identidades complementares é, portanto, correlativo da ilusão que torna o amor um dos possíveis destinos da castração. O problema é que, ao crer-se em demasia, suporta-se pouco a queda das certezas. A sexuação como sintoma é frágil; as vicissitudes da vida - o casamento, a maternidade e a paternidade, as mudanças do esquema corporal que a idade acarreta, etc. - estão constantemente a nos demandar provas de nossa consistência identitária. Pode-se passar a vida buscando encontrar o outro complementar que, pelo amor, garantiria a identidade. Alguns casais dão provas desse encontro e optam por assegurar-se mutuamente, até o fim de seus dias. Do ponto de vista cultural, esta é a resposta estética à falta de sentido da vida - castração simbólica — que mais apreciamos. 
A morte é outra expressão do encontro/desencontro entre os sexos. Ela também é uma crença - como apropriadamente indica Freud — posto que da morte não temos a experiência (FREUD, 1922/1973). O registro que fazemos é sempre o da perda do outro. Mas, nesse sentido de perda, a morte é antes uma fantasia de união, atinente ao amor. Há, no entanto, um empuxo - uma força motriz - que nos conduz, enquanto seres sexuados, ao aniquilamento. Freud o denomina de pulsão de morte. Sua direção não visa à produção de sentido. O que pauta seu curso, Lacan (1972-73/1985) denomina de gozo. Trata-se, antes, de um retorno: a pregnância subjetiva ao estado primitivo de objetalização, de alienação absoluta ao Outro. É, pois, do gozo do Outro que se trata na pulsão de morte, posto que ao sujeito cabe apenas fazer-se objeto.

Esta faceta da relação entre sexos constitui o eixo principal da fantasia que promove o prazer sexual. Seja na identificação à posição de domínio ou à posição da submissão - o fantasma sadomasoquista agenciado pela reunião entre Eros e pulsão de morte - determina o desempenho de papéis sexuais definidos previamente pelo esquema. Nas rupturas das identidades amorosas, são as máscaras do gozo que os humanos se aprazem em utilizar.

Como demonstramos, o ser sexuado passa, também, pelo suporte desta máscara; as condições de obtenção de prazer no sexo sendo determinadas pela forma como se supõe fazer o Outro gozar do seu corpo. Na passividade comum a ambos os corpos, instrumentalizados no sexo, o prazer manifesta-se como suplência a interditar este gozo. Separação do objeto a nos fluidos corporais ejetáveis e reintegração do sujeito à condição de domínio. As identidades são pouco afeitas ao exercício sexual; neste terreno comportam — no máximo - a identificação com o objeto ao qual, no final, vêem o ato reduzido.

Por fim, a expressão de um gozo Outro, denominado assim por Lacan (197273/1985) ao referir-se aos modos de sexuação suplementares ao gozo fálico. Seria um gozo específico da mulher, no sentido da alteridade que elas alegoricamente constituem - uma a uma — à ficção do Um. No lugar da unidade fálica, o infinito deslizamento da letra pulsional. Na cultura, a produção dos místicos seria a expressão desta forma de gozo. A possibilidade de constituição de um registro e transmissão da posição da letra no inconsciente que dispense a máscara das identidades é o que os escritos desses autores nos testemunham. Por isso, seu caráter de produção suplementar ao registro fálico e que traz a marca de uma produção singular. O gozo Outro é, assim, o que mais nos aproxima da possibilidade da constituição de uma inscrição singular da enunciação que sendo sexuada dispensa o recurso às identidades sexuais. 


\section{O SEXO NO OLHAR DA CIÊNCIA}

No texto Psicogênese de um caso de homossexualidade feminina, Freud (1920/1973) distingue três níveis de análise em relação às questões de gênero: identidade psíquica (atividade/passividade), escolha de objeto e caracteres sexuais anatômicos. Ele afirma a independência entre estes três termos. Trata-se de uma posição ousada e inovadora no campo da sexualidade. Ela encontra ressonância ainda hoje nos “estudos de gênero” que partem justamente dessa distinção (BUTLER, 2003).

Por outro lado, mesmo que em Freud já encontremos as bases para relativizar o pênis como falo e a castração como temor — portanto como representação psíquica e não dado natural — o apelo explícito à anatomia na definição dos destinos psíquicos não deve deixar de nos fazer questão. Nesse ponto, aliás, é preciso lembrar: Freud não está só. Ele compartilha da opinião corrente em sua época. Ou melhor: ele expressa o pensamento do século 19 no auge da ebulição, nos anos de 1920, de um novo paradigma, próprio a este novo século. O que surpreende é que, sendo o autor muito pouco comprometido com questões de cunho moral, ele se coloque justamente na defesa de um aspecto que reconhecemos - e já na época em que ele o enunciava era assim — como preconceituoso. Por que ele assume tal posição?

Acreditamos que o que fez com que o psicanalista compactuasse com a misoginia do século 19 foi a sua intensa implicação com o discurso da ciência desse mesmo período. De alguma forma, para esse discurso, a questão da diferença anatômica entre os sexos era uma premissa necessária e fundamental. A questão que permanece, então, é: por que a ascensão da ciência moderna incidiu, em termos políticos, diretamente sobre o sexo e de que forma a diferença anatômica serviu de argumento último para justificação de seus princípios?

Sabe-se, por exemplo, que os termos "hetero" e "homossexualidade" são criações taxonômicas do século 19; da mesma forma que os catálogos das “perversões sexuais". Vale lembrar também que, mesmo que as mulheres e os homens tenham historicamente - e até pouco tempo - ocupado lugares sociais bastante distintos, não se atribuía à anatomia, ao desempenho sexual ou às preferências eróticas essa diferença. Fazer corresponder ao sexo anatômico, e ao exercício sexual, o lugar e a função social de cada um é traço próprio à modernidade. É neste período, historicamente circunscrito, que de fato o pênis se confunde com o falo.

Em número recente da revista Isto é (2005), encontramos uma confirmação chistosa (se não fosse verdadeira) do enlace político entre discurso científico e diferença anatômica. Pode-se ler aí que o reitor da Universidade de Harvard declarou que as mulheres têm mais dificuldade de aprender disciplinas científicas se comparadas aos homens. Para o reitor, haveria uma diferenciação inata entre os sexos que explicaria o menor número de mulheres cientistas. É muito curioso 
que em pleno século 21 uma figura de autoridade possa, aparentemente sem constrangimentos, afirmar assim seu preconceito e produzir, com base numa argumentação cientifica, um sofisma segregacionista. Não nos parece casual que seja uma autoridade na ciência que se valha desse discurso para justificar suas opiniões.

Cabe lembrar, em relação à ciência, que — como Lacan (1966/1998) indica — ela se constitui como saber pela forclusão do lugar da verdade. Os enunciados científicos se fundamentam pela exclusão do sujeito da enunciação; ele é pressuposto, mas não pertence ao campo próprio desse discurso. Assim, o discurso da ciência se estabelece como "reino do enunciado", dirigido pela premissa da objetividade. Há uma cisão estrutural entre o que é dito e aquele que o diz, entre saber e verdade.

O que é particularmente interessante é que, no discurso da ciência moderna a forclusão do sujeito da enunciação retorna pela posta em causa do sexo, como demanda de significação sexual. Dito de outro modo, a necessária exclusão do sujeito da consideração científica - forclusão que é o fundamento desse discurso - é correlativa ao estranhamento do sujeito em relação às funções sexuais. Ao buscar responder pela significação apoiando-se na anatomia, o sujeito repete — de forma ativa — a exclusão promovida pelo discurso. No lugar de responder pela sua posição no desejo, aponta para a anatomia: “veja”, “eu sou homem” ou "eu sou mulher". 2

Assim, que a ciência, ou melhor, os cientistas - e entre eles Freud — tentem dar conta da ausência de significação recorrendo a uma suposta objetividade da anatomia, não é de se estranhar. De novo, o sujeito da enunciação é elidido, situado em uma posição de exterioridade em relação a um corpo delegado pelo Outro; corpo cujo destino viria traçado pelos desígnios da diferença anatômica. Como se o reitor da Universidade de Harvard dissesse: sou reitor dessa importante universidade e justifico minha posição de autoridade pelo fato científico, objetivamente demonstrado pela anatomia, de que sou homem.

Um ponto importante ainda a considerar é que a dita “objetividade” científica denota determinada posição do olhar na produção de um saber sobre o sujeito. É no trabalho de Foucault que vamos encontrar apoio para abordar essa questão. O discurso científico da anatomia, e a produção de significação que ele visa, se pauta, segundo o autor, pelo seguinte postulado: “que todo o visível é enunciável e que é inteiramente visível, porque é integralmente enunciável" (FOUCAULT, 1980/2004, p.127). Há entre o olhar e o dizer uma íntima articulação que comanda o dis-

\footnotetext{
${ }^{2}$ Que hoje a referência sexuada no discurso da ciência tenha sido deslocada da anatomia para o código genético muda pouco a lógica da questão. Tanto o corpo quanto as letras da genética são "lidos" pela ciência como símbolos e não como significantes. Isto é, comportam uma referencia biunívoca na qual não há lugar para o sujeito do desejo.
} 
curso da ciência produzindo, a um só tempo, exclusão do sujeito e significação sexual. Trata-se de uma significação externa ao sujeito: um saber universal ao qual cada ser sexuado busca se adequar; saber instrumental que organiza jogos de poder, reduzindo o sujeito à condição de objeto de seu gozo.

A apresentação do discurso da ciência como forma de organização de poder é trabalhada por Foucault (1973-74/2003) a partir da referência histórica de seu surgimento. Segundo o autor, pode-se identificar no século 18 uma transição entre duas formas distintas de organização: do poder soberano ao poder disciplinar. Esta modificação é contemporânea da instalação do que ele denominou de "dispositivo da sexualidade” (FOUCAULT, 1988), referindo-se à inscrição na cultura de um circuito discursivo articulado pela conjunção entre corpo, saber e poder. Este dispositivo se expressa tanto como intensificação do prazer, como pela produção de saber, verdade e domínio das/nas manifestações corporais/sexuais.

Sob o domínio das disciplinas, a conjunção entre poder e saber é regulada sobretudo pelo olhar (FOUCAULT, 1975). Se retomarmos os textos freudianos das décadas de 1920 e 30 - textos nos quais ele apresenta a formulação teórica da fase fálica e do complexo de Édipo - destaca-se o fato de que a verdadeira primazia designada por Freud é justamente a primazia do olhar. Sob o pano de fundo da crença na universalidade do falo, a instalação do complexo de castração é fruto de uma constatação, de um "testemunho ocular” do sujeito. O pênis é o falo porque é visível e se o sexo feminino faz enigma, representando na fase fálica a castração, é porque ele não se dá a ver (KEHL, 2004).

Assim também, o repúdio perverso da castração é de início nomeado por Freud (1927/1973) como um processo de escotomização, isto é, uma cisão do olhar que indica uma recusa a ver. Também na cena primária, a posição de exterioridade do sujeito que olha, situa um tempo do exercício da pulsão escópica no qual o sujeito goza da exclusão. Já na constatação da diferença anatômica a partir da visão da ausência do pênis — em si próprio ou no outro — o sujeito está irremediavelmente incluído no jogo de ausência e presença. A angústia de castração é efeito desta inclusão na cena, do retorno do olhar sobre o sujeito.

A partir destas colocações, destacam-se dois operadores: o falo simbólico como pressuposto discursivo e o olhar como exercício pulsional. Desta articulação, temos as diferentes configurações do poder e do sexo: a sua sobreposição, a sua mútua alienação.

Esta articulação não é nova: reconhece-se aí o modelo proposto por Lacan (1949/1998) no "Estágio do espelho" — falo e olhar como instâncias do Outro que permitem à criança a constituição do fantasma, a sobreposição entre falta no corpo e falta no discurso. O que a leitura de Foucault nos permite avançar é de como, efetivamente, este laço fantasmático constitutivo do sujeito tem, na 
história da cultura, variações possíveis, transformações que tocam a relação entre corpo e significante, entre pulsão e discurso.

Não há, pois, nenhum suporte natural neste domínio. Neste sentido, é bastante compreensível que a presença ou ausência do pênis tenha situado, na modernidade, posições fixas no laço social. A perda deste centramento, deste referente único da diferença, conduz/é resultado de novas formas de articulação corpo-poder: as expressões do racismo o atestam. Elas são tão maléficas quanto a segregação entre os sexos. Não há medida de valor possível para o "menos pior" neste caso. O que se pode pensar como sendo um avanço de nosso tempo é a possibilidade de estabelecer uma clivagem entre olhar e falo, a partir do qual - tornados independentes um do outro — a sua necessária associação pode assumir configurações diversas.

Recebido em 21/9/2006. Aprovado em 3/4/2007.

\section{REFERÊNCIAS}

ALTHUSSER, L. (1985) Freud e Lacan, Marx e Freud. Rio de Janeiro: Edições Graal.

BUTLER, J. (2003) Problemas de gênero: feminismo e subversão da identidade. Rio de Janeiro: Civilização Brasileira.

COSTA, A.M.M. (1998) A ficção do si mesmo. Rio de Janeiro: Companhia de Freud.

FOUCAULT, M. (1973-74/2003) Le pouvoir psychiatrique. Paris: Gallimard/ Seuil.

(1975) Surveiller et punir. Paris: Gallimard.

(1980/2004) O nascimento da clínica. Rio de Janeiro: Forense Universitária.

(1988) História da sexualidade I: a vontade de saber. Rio de Janeiro: Edições Graal.

. (1988b) Isto não é um cachimbo. Rio de Janeiro: Paz e Terra.

FREUD, S. (1973) Obras completas. Madrid: Biblioteca Nueva.

(1905) “Tres ensayos para una teoria sexual”, tomo II, p.1.169-

1.237.

(1909) “La novela familiar del neurótico”, tomo II, p.1.361-1.364.

(1910) "Sobre un tipo especial de la elección de objeto en el hombre", tomo II, p.1.625-1630.

(1910b) "Un recuerdo infantil de Leonardo de Vinci", tomo II, p.1.5771.619.

(1912) “Sobre una degradación general de la vida erótica”, tomo II, p.1.710-1.717.

(1914) “Introducción al narcisismo", tomo II, p.2.017-2.034.

(1915) “Los instintos y sus destinos”, tomo II, p.2.039-2.052. 
(1917) “Una dificultad del psicoanalisis”, tomo III, p.2.432- 2.436.

(1920) "Sobre la psicogénesis de un caso de homosexualidad feminina”, tomo III, p.2.545-2.562.

(1922) "La cabeza de medusa", tomo III, p.2.697.

(1923) "La organización genital infantil (adicion a la teoria sexual)", tomo III, p.2.698- 2.700 .

(1924) “La disolución del complejo de Edipo”, tomo III, p.2.7482.751 .

(1925) "Algunas consecuencias psiquicas de la diferencia sexual anatômica”, tomo III, p.2.896-2.903.

(1927) "Fetichismo", tomo III, p.2.993-2.996.

(1931) "Sobre la sexualidad feminina”, tomo III, p.3.077-3.089.

(1933) “Lección XXXIII: La feminidad”, tomo III, p.3.164-3.177.

ISTO É (2005), n. 1.841, São Paulo: Editora Abril, 26 de janeiro de 2005, p.21.

JERUSALINSKY et al. (2005) Masculinidade em crise. Porto Alegre: Appoa.

KEHL, M. R. (2004) A impostura do macho. Revista da Associação Psicanalítica de Porto Alegre, n.27. Porto Alegre, p.90-102.

LACAN, J. (1949/1998) “O estágio do espelho como formador da função do eu”, in Escritos. Rio de Janeiro: Jorge Zahar.

(1957/1998) “A instância da letra no inconsciente ou a razão desde Freud", in Escritos. Rio de Janeiro: Jorge Zahar. (1957-58/1999) O Seminário livro 5, As formações do inconsciente. Rio de Janeiro: Jorge Zahar. (1958/1998) “A significação do falo", in Escritos. Rio de Janeiro: Jorge Zahar.

. (1962-63/2005) O Seminário livro 10, A angústia. Rio de Janeiro: Jorge Zahar. . (1964-65/2000) Problèmes cruciaux pour la psychanalyse. Edição não comercial da Association Freudienne Internationale. . (1966/ 1998) "A ciência e a verdade", in Escritos. Rio de Janeiro: Jorge Zahar.

(1971/1994) D’un discours qui ne serait pas du semblant. Edição não comercial da Association Freudienne Internationale. (1972-73/1985) O Seminário livro 20, Mais, ainda. Rio de Janeiro: Jorge Zahar.

POLI, M.C. (2004) Segregação urinária. Revista da Associação Psicanalítica de Porto Alegre, n. 27. Porto Alegre, p.18-27. (2005) "Sexo e poder: diálogo com Michel Foucault", in Masculinidade em crise. Porto Alegre: Appoa.

ORLAN (1989/2006) L'origine de la guerre. Disponível em: http:// www.orlan.net/fr. Acesso em: setembro de 2006.

ROUDINESCO, E. (1994) Jacques Lacan: esboço de uma vida, história de um sistema de pensamento. São Paulo: Companhia das Letras. 